\title{
Extraperitoneal cesarean section: a retrospective analysis
}

\section{Partha Pratim Sharma, Sneha Gond*, M. D. Kamaluddin Ansari, Narra Madhuri, Surendra N. Bera}

Department of Gynaecology and Obstetrics, Midnapore Medical College, Paschim Medinipur, West Bengal, India

Received: 20 December 2019

Revised: 27 January 2020

Accepted: 01 February 2020

\section{*Correspondence:}

Dr. Sneha Gond,

E-mail: snehagond1591@gmail.com

Copyright: (c) the author(s), publisher and licensee Medip Academy. This is an open-access article distributed under the terms of the Creative Commons Attribution Non-Commercial License, which permits unrestricted non-commercial use, distribution, and reproduction in any medium, provided the original work is properly cited.

\section{ABSTRACT}

Background: Morbidity of caesarean section still persist in terms of pain, infection and adhesion. This study will focus on different morbidities associated with ECS.

Methods: A retrospective analysis of 29 ECS were included from June to September 2018, done at Midnapore Medical college, West Bengal, India.

Results: Contracted pelvis $(12 / 29,41.37 \%)$ and cephalopelvic disproportion $(10 / 29,34.48 \%)$ were common indications for ECS. Mean gestational age was $39.65 \pm 1.31$ weeks and birth weight were $3.01 \pm 0.40 \mathrm{~kg}$. Time taken for ECS was $33.06 \pm 10.85$ minutes. Extension of uterine incision and mild distension of abdomen occurred in $3.44 \%$ each. Post-operative period was uneventful and all discharged after 72 hours of operation.

Conclusions: ECS can be performed safely by experienced hands with less feto-maternal morbidity and early discharge of mother and baby.

Keywords: Delivery time, Discharge, Extraperitoneal cesarean section, Feto-maternal morbity

\section{INTRODUCTION}

Extraperitoneal caesarean section is a method of surgically delivering a baby through an incision in the lower abdomen without entering into the peritoneal cavity. The uterus is approached through the paravesical space. This procedure is performed most often to prevent the spread of infection from the uterus into the peritoneal cavity. ${ }^{1}$ Advantages of ECS over classical/ transperitoneal caesarean section (TCS) are no bowel handling, minimum chances of intra peritoneal infections, no chances of losing a surgical mop into the peritoneal cavity and adhesion. Main objective of this study is to analyse feto-maternal outcome and morbidities associated with ECS.

\section{METHODS}

It is a retrospective study of pregnant women, who were posted for delivery by ECS, 29 patients were included in study over a period of four months from June to September 2018, done at Midnapore Medical college and Hospital, West Bengal. In this study 26 primi, 2 patients were 2 nd gravida and 1 patient was $3^{\text {rd }}$ gravida. Data were collected from OT register and case record in the department of obstetrics and gynecology. The parameters noted were the age, parity, gestational age at delivery, presentation, details of treatment and neonatal outcome such as birth weight and Apgar score. Statistical analysis was done by percentage and mean of the value were calculated where it is appropriate. 


\section{Inclusion criteria}

- Patients with term pregnancy admitted through OPD or Emergency were included, those who were given spinal anesthesia without above mentioned condition planned for LSCS and included in study.

\section{Exclusion criteria}

- Patients with abnormal placentation, abruption, nonvertex presentation, multiple pregnancy, cord prolapse, post cesarean pregnancy and associated medical and surgical conditions where TCS is the preferred for delivery of fetus.

ECS was done under spinal anaesthesia. Bladder was catheterized. Supra-pubic low transverse incision given. After transverse incision of rectus sheath and separation of rectus and pyramidalis muscle longitudinally, transversalis fascia was separated medial to inferior epigastric vessels. Medial umbilical ligament is the lateral border of bladder. Bladder pushed medially now, to expose utero vesical fold of peritoneum. Separation of vesico-cervical fascia done and uterine incision given to deliver the fetus followed by placenta and membranes. Now uterus closed in layers as done in TCS, followed by rectus sheath and skin. Injection oxytocin given after delivery of the baby.

\section{RESULTS}

There were 29 delivery during the study period done by ECS. All were at term with cephalic presentation. Age group were between 18 to 32 years and mean age was $21.31 \pm 2.62$ years. Out of 29 women $26(89.65 \%)$ were primigravidae, followed by gravidae $2^{\text {nd }}(6.89 \%)$ and $3^{\text {rd }}$ (3.44\%), undergone ECS.

Table 1: Indications of ECS.

\begin{tabular}{|lll|}
\hline Indications & $\begin{array}{c}\text { no. of cases } \\
(\mathbf{n = 2 9})\end{array}$ & \% \\
\hline Contracted pelvis & 12 & $41.37 \%$ \\
\hline Cephalo pelvic disproportion & 10 & $34.48 \%$ \\
\hline Elderly primigravidae & 03 & $10.34 \%$ \\
\hline IUGR & 02 & $6.89 \%$ \\
\hline Meconium stained liquor & 02 & $6.89 \%$ \\
\hline
\end{tabular}

Table 1 shows indications of ECS. Contracted pelvis $(12 / 29,41.37 \%)$, cephalopelvic disproportion (10/29, $34.48 \%)$, elderly primi $(3 / 29,10.34 \%)$, IUGR $(2 / 29$, $6.89 \%)$ and meconium stained liquor $(2 / 29,6.89 \%)$ were the indications for ECS in the present study.

Success rate of ECS was $93.10 \%$ (27/29) and in 6.89\% (2/29), unintended entry into the peritoneum occurred during ECS.
Incision to delivery of fetus were less than 5 minutes in $62.06 \%(\mathrm{n}=18)$, followed by 5 to 9 minutes in $31.03 \%$ $(n=9)$, and more than 9 minutes in $6.89 \%(n=2)$ cases. Skin incision to skin closure time was less than 30 minutes in $62.06 \%$ (18) ECS followed by $27.58 \%$ (8) taken $30-45$ minutes and in $10.34 \%$ (3) more than 45 minutes. Post-partum haemorrhage not occurred in any women as shown in the Table 2. All mother and babies were well and discharged after 72 hours of ECS.

Table 2: Outcome of the present study.

\begin{tabular}{|lll|}
\hline Outcome $(\mathbf{n}=\mathbf{2 9})$ & Mean & $\%$ \\
\hline Gestational age & $39.65 \pm 1.31$ weeks & - \\
\hline Birth weight & $3.01 \pm 0.40 \mathrm{~kg}$ & - \\
\hline $\begin{array}{l}\text { Apgar score at } 1 \\
\text { minute }\end{array}$ & $7.24 \pm 0.87$ & - \\
\hline Delivery time & $4.96 \pm 2.39$ minutes & - \\
\hline Operation time & $33.06 \pm 10.85$ minutes & - \\
\hline Intravenous fluid & $15.72 \pm 2.11$ hours & - \\
\hline Adhesion & - & $0 \%$ \\
\hline $\begin{array}{l}\text { Broad ligament } \\
\text { hematoma }\end{array}$ & - & $0 \%$ \\
\hline $\begin{array}{l}\text { Extension of uterine } \\
\text { incision }\end{array}$ & - & $3.44 \%$ \\
\hline Chorioamnionitis & - & $0 \%$ \\
\hline Abdominal distension & - & $3.44 \%$ \\
\hline $\begin{array}{l}\text { Intestinal peristalsis } \\
\text { sound present }\end{array}$ & - & $100 \%$ \\
\hline Pyrexia & - & $0 \%$ \\
\hline $\begin{array}{l}\text { Ambulation within } 16 \\
\text { hours after ECS }\end{array}$ & - & $89.65 \%$ \\
\hline Postpartum hemorrhage & - & $0 \%$ \\
\hline $\begin{array}{l}\text { Discharge after } 72 \\
\text { hours of ECS }\end{array}$ & - & $100 \%$ \\
\hline
\end{tabular}

\section{DISCUSSION}

Lower segment of uterus is extraperitoneal like urinary bladder, ureter, kidneys. TCS are commonly done by Obstetricians. Surgeons who are comfortable and have knowledge about lower uterine segment and paravesical area of pelvis can do the ECS with ease. Authors are familiar with TCS but ECS has definite advantage of less pain, infection, invasiveness, minimum tissue handling, less intra venous fluid requirement, early return of bowel sounds, early ambulation and with the ease of doing next cesarean section as chances of adhesion is less. There are also disadvantages of ECS like chances of bladder trauma, angle extension, inferior epigastric vessel injury, approach to broad ligament hematoma and time taken for operation.

First reports about ECS techniques were described in the early 1900 by Frank, subsequently modified by Latzko. ${ }^{2}$ LiJJ et al, mentioned that extraperitoneal approach was once widely used before the introduction of metronidazole to the medical world in $1960 .^{3}$ 
The indications of ECS are labour over 24 hours, ruptured membranes over 24 hours, induction by bougie, six or more vaginal examinations and evidence of intrauterine infection. ${ }^{4}$ Bebincy DS et al reported most of the mother were primipara in the ECS group compared to TCS group where previous LSCS group were more. ${ }^{5}$ In the present study, 26 were primigravidae and other three had previous vaginal delivery who were posted for ECS with different indications (Table 1).

Yesilbas $\mathrm{C}$ et al, reported that duration of surgery ( $\mathrm{p}<$ $0.001)$ and delivery time $(p=0.145)$ was shorter in the ECS group compared to TCS group. ${ }^{6}$ In another study by Bebincy DS et al, reported that Apgar score at 1 minute in ECS and TCS were same (7.9 versus 8) though duration of surgery (29.48 versus 26 minutes) and delivery time (4.57 versus 2.05 minutes) was more in the ECS group. ${ }^{5}$ In the present study (Table 2) mean duration of ECS was $33.06 \pm 10.85$ minutes and mean delivery time was 4.96 \pm 2.39 minutes and mean Apgar score at 1 minute was $7.24 \pm 0.87$ which is almost similar to the above study done by Bebincy DS et al. ${ }^{5}$

Yesilbas $\mathrm{C}$ et al also reported that early return of flatus within 12 hours $(11.2 \pm 1.5)$ and less post-operative pain were significant after ECS. ${ }^{6}$ Bebincy DS et al also reported early return of bowel sounds and post-operative wound infection was nil. ${ }^{5}$ This study showed that Intestinal peristalsis sound was present in all, intravenous fluid required for $15.72 \pm 2.11$ hours and ambulation within 16 hours were $89.65 \%$ in the present study (Table 2).

Hofmeyr JG et al, Zlatan F et al reported that advantages of Misgav- Ladach cesarean section (TCS) are lower incidence of fever, reduced use of antibiotics, reduced operating time, blood loss, time to mobilization, length of post-operative stay for the mother and less post-operative adhesion formation. ${ }^{7,8}$ However, present study findings are almost similar to the above mentioned studies by Bebincy DS et al and Yesilbas C et al.,56

Tappauf $\mathrm{C}$ et al found that post-operative pain, usages of analgesics and intra-operative nausea with no increased complications in the ECS group. ${ }^{9}$ Infusion paracetamol and diazepam were given in the post-operative period in the present study. They also reported that drop in haemoglobin levels was not different between ECS and TCS group. Table 2 shows postpartum haemorrhage was nil in the present study.

\section{CONCLUSION}

Extraperitoneal caesarean section is safe procedure in experienced hands with less feto maternal morbidity and early discharge of mother and baby. There are many advantages of ECS but authors are not practising it, so the learning curve is becoming harder. Resident in Obstetrics can attend workshop, see it in the You Tube and work with senior doctor to learn this art of doing ECS which is still relevant in the present time.

\section{Funding: No funding sources}

Conflict of interest: None declared

Ethical approval: The study was approved by the Institutional Ethics Committee

\section{REFERENCES}

1. Zabransky F, Grossmannova H. Extraperitoneal caesarean section-an alternative or routine? Ceska Gynecol. 2001;66(3):187-9.

2. Pandit SN, Sahu R, Kale DP. Cesarean Section. In: Kar T, Kar A, editors. Do's and dont's in obstetrics and gynecology practice. New Delhi: Jaypee Brothers; 2012:99-130.

3. Li JJ, Corey EJ, (editors). Drug discovery: Practices, process and perspectives. Hoboken, NY: John Wiley and Sons; 2013:P27.

4. Paternite CJ, Bachand MS. Extraperitoneal caesarean sections: analysis of 93 consecutive operations. Obstet Gynecol. 1954;3(3):283-6.

5. Bebincy DS, Chitra J. Extraperitoneal versus transperitoneal caesarean section in surgical morbidity in a tertiary care centre. Int $\mathbf{J}$ Reprod Contracept Obstet Gynecol. 2017;6(8):3397-9.

6. Yesilbas C, Erenel H. Extraperitoneal versus transperitoneal cesarean section: a retrospective analysis. Perinatal J. 2017;25(1):38-42.

7. Hofmeyr JG, Novikova N, Mathai M, Shah A. Techniques for caesarean section. Am J Obstet Gynecol. 2009;201:431-44.

8. Zlatan F, Igor H, Asim M. Misgav-ladach cesarean section: general consideration. Acta Clin Croat. 2011;50:95-9.

9. Tappauf C. Extraperitoneal versus transperitoneal caesarean section: a prospective randomised comparison of surgical morbidity. Am J Obstet Gynecol. 2013;209(4):338e1.

Cite this article as: Sharma PP, Gond S, Ansari MDK, Madhuri N, Bera SN. Extraperitoneal cesarean section: a retrospective analysis. Int J Reprod Contracept Obstet Gynecol 2020;9:1089-91. 